\title{
Investigation on the Carbon Monoxide Pollution over Peninsular Malaysia Caused by Indonesia Forest Fires from AIRS Daily Measurement
}

\author{
Jasim M. Rajab, K. C. Tan, H. S. Lim and M. Z. MatJafri \\ School of Physics, Universiti Sains Malaysia, Penang, \\ Malaysia
}

\section{Introduction}

Carbon monoxide $(\mathrm{CO})$ is an important pervasive atmospheric trace gas affecting climate and more than $50 \%$ of air pollution nationwide and worldwide, which also plays as a significant indirect greenhouse gases due to its influences on the budgets of hydroxyl radicals $(\mathrm{OH})$ and ozone $\left(\mathrm{O}_{3}\right)$. We present a study on Atmosphere Infrared Sounder (AIRS), onboard NASA's Aqua Satellite, detection of CO emission from large forest fire in the year 2005 in the Sumatra, Indonesia. AIRS daily coverage of $70 \%$ of the planet symbolizes an important evolutionary advance in satellite trace gas remote sensing. AIRS is one of several instruments onboard the Earth Observing System (EOS) launched on May 4, 2002, with its two companions microwave instruments the Advanced Microwave Sounding Unit (AMSU) and the Humidity Sounder for Brazil (HSB) form the integrated atmospheric sounding system. AIRS providing new insights into weather and climate for the 21st century, as well as AIRS' channels include spectral features of the key carbon trace gases $\mathrm{CO}_{2}$, methane $\left(\mathrm{CH}_{4}\right)$, and $\mathrm{CO}$. AIRS is an infrared spectrometer/radiometer that covers the 3.7$15.4 \mathrm{~m}$ spectral range with 2378 spectral channels. Troposphere $\mathrm{CO}$ abundances are retrieved from AIRS $4.55 \mathrm{~mm}$ spectral region, and measure CO total column by 52 channels with the uncertainty, which is estimated approximately $15-20 \%$ at $500 \mathrm{mb}$. Results from the analysis of the retrieved CO daily Level 3 standard (AIR $\times 3$ STD) and Monthly product (AIRX3STM) were utilized in order to study the impact of Indonesia forest fire on CO distribution, and the monthly CO distributions in Peninsular Malaysia. AIRS daily CO maps from 12 - 25 August 2005 for study area show large-scale, long-range transport of CO from anthropogenic and natural sources, most notably from forest fire biomass burning. The sequence of daily maps shows the $\mathrm{CO}$ advection from central Sumatra to Malaysia. AIRS can also capture the temporal variation in $\mathrm{CO}$ emission from forest fires through 6-day composites so it may offer a chance to enhance our knowledge of temporal fire emission over large areas. The result was compared with daily CO emission (13-24) August 2007. The daily measurements of CO concentration on August 2005 are higher than August 2007. The northern region (uppers the latitude 4) was more affected by forest fires than the rest area. Substantial seasonal variations demonstrate season-to-season changes in rainfall and drought patterns in different seasons. We see such seasonal variations in the biomass burning emissions in the late dry season, while industrial contributions are evident at 
smaller magnitudes on monthly distributions. The study shows that AIRS can reliably detect $\mathrm{CO}$ plumes from forest fires in $1^{\mathrm{o} *} 1^{\circ}$ spatial resolutions. The $\mathrm{CO}$ maps were generated using Kriging Interpolation technique.

$\mathrm{CO}$ is an important atmospheric constituent affecting climate and air quality, which also acts as an important indirect greenhouse gases as it significantly impacts the $\mathrm{OH}$ budget, and thus indirectly affects the $\mathrm{CH}_{4}$ and $\mathrm{O}_{3}$ concentrations. This is due to the characteristic of $\mathrm{CO}$ by the indirect radiative forcing effect and increases the concentrations of troposphere $\mathrm{O}_{3}$ and $\mathrm{CH}_{4}$ through chemical reactions with other atmospheric constituents. It is approximately $75 \%$ of $\mathrm{OH}$ sinks, which is capable to influence the concentration of greenhouse gases, the oxidizing agent in troposphere and finally contributes to climate change (Daniel and Solomon, 1998). CO is not a significant greenhouse gas because of it weak absorption of infrared radiation from the Earth. In addition, CO is useful in many modern technology applications, such as in bulk chemicals manufacturing.

It is very important to observe and document changes in the forcing terms such as gases, in order to understand and assess their influences of climate change, and to achieve more dependable longer range projections. Over the past three decades, the abundances of the atmosphere parameters (gases) were obtained from a lot of sources such as balloons, airplane and sparsely distributed measurement sites. While the observations were mostly limited to the surface and give important insights on flux variability the estimates have large uncertainties because there is not much atmospheric concentration data and more sensitive to sources and sinks. In situ measurements normally have the best accuracy from ground and aircraft, but the major shortfall is not being able to make daily global variation evaluations as well as cost a lot of money and strenuous efforts. There is a lack of data both in the lower - particularly over land - and upper troposphere (Tiwari et al., 2005).

A potentially favourable measurement method for closing some of these data gaps are the retrieval of gases from space. The satellite remote sensing has very good global coverage increase our capability to access the influence of human activities on the chemical composition of the atmosphere and on the climate changes (Clerbaux et al., 2003). Furthermore, can provide the quantitatively data with high spatial or temporal resolution (Dousset \& Gourmelon, 2003). In addition, the free download satellite data provided by infrared measurements from the Atmospheric InfraRed Sounder (AIRS) on the NASA AQUA satellite to establish and produce the high quality spectrally resolved radiance climatologic for observing and detecting climate change, to understand the distribution of trace gases, sources and sinks, and to validate weather and climate models.

From $705 \mathrm{~km}$ above the Earth's surface, the AIRS measure the integrated impact of numerous atmospheric molecules emitting and absorbing radiation at various temperatures throughout the atmospheric path from the surface to the instrument. The AIRS, included on the EOS Aqua satellite launched on May 4, 2002, is the first of the new generation of meteorological advanced sounders for operational and research use (Aumann et al., 2003).

In Malaysia, one of Southeast Asia country, industrialization, urbanization and rapid traffic growth have contributed significantly to economic growth. Pockets of heavy pollution are being created by emissions from major industrial zones, a dramatic increase in the number of residences, office buildings, manufacturing facilities, increases in the number of motor vehicles and trans-boundary pollution. Besides that, Malaysia is situated in a humid tropical zone with heavy rainfall and high temperatures (Mahmud \& Kumar, 2008; Tangang et al., 
2007); the cloudy conditions cover the study area becomes the obstacle to acquire a high quality and resolution for satellite data.

The AIRS ability to provide simultaneous observations of the Earth's atmospheric temperature, water vapour, land surface temperature and the distribution of greenhouse gases (GHG's) with cloud clearing system, makes AIRS/AMSU a very functional space instrument to observe and study the atmosphere reaction to increased several gases such as CO. AIRS with its two companion microwave instruments, (AMSU) and (HSB), form the integrated atmospheric sounding system (Lambrigtsen, 2003). AIRS is an infrared spectrometer/radiometer that covers the 3.7-15.4 m spectral range with 2378 spectral channels and used to measure the upwelling radiance from Earth (Strow et al., 2003).

In addition, AIRS is the first hyperspectral infrared radiometer designed, in order to provide a valuable data for National Ocean and Atmospheric Administration's National centers for Environmental Prediction (NCEP) and other weather forecasting centers, for the operational requirements in terms of weather forecasting in medium-range (Aumann, 2003). AMSU is a 15-channel microwave radiometer operating between 23 and $89 \mathrm{GHz}$. HSB is a four-channel microwave radiometer that makes measurements between 150 and $190 \mathrm{GHz}$ (Lambrigtsen, 2003). It also provides information for several greenhouse gases, $\mathrm{CO}_{2}, \mathrm{CH}_{4}, \mathrm{CO}$ and $\mathrm{O}_{3}$ as well as to improve weather prediction and study the water and energy cycle. AIRS measure $\mathrm{CO}$ total column by 52 channels with the uncertainty, which is estimated approximately 15$20 \%$ at $500 \mathrm{mb}$.

Between 1 August 2005 and 15 August 2005, the central, northern and eastern parts of Peninsular Malaysia experienced severe haze (DOE, 2005). Immense plumes of the gas emitted from forest and grassland burning in Indonesia forest fires in 2005 caused serious air pollution in Malaysia, and the air pollution reached extremely hazardous levels and forced schools and an airport to close. The fires affected 10,000 hectares of peat forest in Sumatra between Riau and north Sumatra. NOAA recorded 5420 hotspots from satellite images over the area between mid-July and mid-August (Jasim et al., 2009). The land and forest fires in the Riau Province of central Sumatra, Indonesia were the primary cause of transboundary pollution which was aggravated by the stable atmosphere conditions during the period. The hazy conditions reached its peak on 11-12 August 2005 when a haze emergency was declared in two areas in the Klang Valley and Kuala Selangor (DOE, 2005). This study is based on the results from the analysis of CO total column retrievals from AIRS, Standard Level-3 Daily gridded product (AIRX3STD) and Monthly product (AIRX3STM) $1 \times 1^{\circ}$ Spatial resolution, Version 5 ascending data, using AIRS IR and AMSU, without-HSB, to investigate the daily distribution map of $\mathrm{CO}$ and the impact of Indonesia's forest fire, and the monthly CO distributions in the Peninsular Malaysia.

The presented AIRS daily Peninsular Malaysia CO maps from 12 - 25 August 2005 for study area show large-scale, long-range transport of $\mathrm{CO}$ from Indonesia forest fires. The sequence of daily maps shows the $\mathrm{CO}$ advection from central Sumatra to Malaysia. The daily measurements of CO concentration on August 2005 are higher than August 2007. The northern region (uppers the latitude 4) was more affected by forest fires than the rest area. Substantial seasonal variations demonstrate season-to-season changes in rainfall and drought patterns in different seasons. We see such seasonal variations in the biomass burning emissions in the late dry season, while industrial contributions are evident at smaller magnitudes on monthly distributions. The $\mathrm{CO}$ maps were generated using Kriging Interpolation technique. In this study, the $\mathrm{CO}$ concentration was accurately and precisely mapped from AIRS data over Peninsular Malaysia. 


\section{Southeast Asia, climatology, and air pollution}

Southern Asia is one of the most heavily populated regions of the world with a vibrant mixture of cultures, which comprises over a quarter of the world's population. One activity which is prevalent to all people amidst this massive diversity is energy consumption, from biomass burning in cook stoves to fossil fuel usage in trucks and rickshaws (Lawrence, 2004). Southeast Asia is experiencing a similar rapid economic growth to that in Northeast Asia. Furthermore, a large source of several air pollutants may make an important contribution to regional and global pollution because of increasing anthropogenic emissions associated with biogenic emissions from large tropical forests. The greater oxidizing capacity in the tropical regions is due to a higher UV intensity, humidity, rapid development and industrialization (Streets et al., 2001).

In addition, Southeast Asia has many social, economic, and environmental impacts caused by forest and land fires. Fires considered one of the largest anthropogenic influences on terrestrial ecosystems after agricultural activities and urban, and its indeed critical elements in the Earth system, vegetation, linking climate, and land use (Lavorel et al., 2007). Tropical haze from peatland has serious negative impacts on the human health and regional economy, and peatland fires affect global carbon dynamics (De Groote et al., 2007).

The strong monsoon and the associated movement of the inter-tropical convergence zone (ITCZ) were dominated the climatology of continental Southeast Asia which mostly located in the equatorial; seasons are not as discrete as in more temperate zones. When the (ITCZ) relocates southern with the sun across Southeast Asia into the Southern Hemisphere, the wintertime winds over considerable of southern Asia usually come from the NE to SW. This region experiences a dry season for about six months (November - April) before the (ITCZ) moves back to the Northern Hemisphere and long-range transport of continental air masses from the Indian Ocean in the summer monsoon prevails during the subsequent wet season (May - October). In the Southeast Asia the dry and wet seasons occur at opposite times of the year due to the difference circulations in the southern and northern hemisphere (Pochanart, 2004).

In the onset of the northeast monsoon, cold surges originating from Siberia and northeast Asia brings significant amount of pollution to southeast Asia while crossing through the heavily-polluted regions of east Asia (Pochanart et al., 2003) and also caused heavy rains which lead to grave flooding in December of some years along east coast and Johor (Tangang et al., 2007). At the same time with strong subsidence in the early dry season, there are important increases in air pollutant levels in continental Southeast Asia (Pochanart, 2004). Maximum air pollutants levels occurs over continental Southeast Asia in the late months of dry season due to strong regional biomass burning and long-range transport of air masses from the western Asia and Middle East. The tropical biomass burning in Southeast Asia is a major source of atmospheric pollutants and strongly influenced by anthropogenic post-agricultural waste burning (Pochanart et al., 2003). In some years the high pollutant levels can be observed in late dry season, were results of La Niña influences combined with the convection in the ITCZ, was considerably weaker than normal, the resulted in incompetent ventilation of the pollutants out of the continental outflow and accumulation of aerosol levels and trace gas in the lower troposphere region (Lawrence, 2004). 


\section{Carbon monoxide pollution}

Carbon monoxide is a colourless, odourless and at high concentration, a poisonous gas. The resulting from fossil fuel combustion has become a major issue, especially in air pollution. $\mathrm{CO}$ is emitted mainly from motor vehicle exhaust, industrial processes and open burning activities (Buchwitz et al., 2007). The situation become worsens for the countries with the instinctive fuel consumption and the increasing energy demand. Carbon monoxide is an important atmospheric constituent affecting climate and a major troposphere air pollutant (Buchwitz et al., 2006). Therefore, it is very important to acquire information regarding the distribution of carbon monoxide. The investigation of carbon monoxide globally has gained attention from researchers recently. It also affects the concentration of greenhouse gases such as methane and ozone. Besides that, carbon monoxide also being a secondary pollutant regarding the respiratory problem and affect the crop yields (Buchwitz et al., 2006).

World-wide, the anthropogenic sources produce about $50 \%$ of $\mathrm{CO}$ emissions with the remainder coming from biomass burning and oxidation of naturally occurring volatile hydrocarbons. $\mathrm{CO}$ is a product of incomplete produced by combustion of fossil fuel and biomass, and having an average lifetime of 2-4 months in the atmosphere (McMillan et al., 2005).

It is generally agreed that biomass burning accounts for about one quarter of $\mathrm{CO}$ emission to the atmosphere and its concentrations in the northern Hemisphere are much higher, where human population and industry are much greater than in the southern Hemisphere. $\mathrm{CO}$ emissions are generally $5-15 \%$ of $\mathrm{CO}_{2}$ emissions from burning, depending on the intensity of the burn (Liu et al., 2005). Andreae \& Merlet (2001) estimated the annual emission of CO from vegetation fires in tropical forests and savannas' is $342 \mathrm{Mt}(1 \mathrm{Mt}=109 \mathrm{~kg}) \mathrm{CO}$ per year, while the total $\mathrm{CO}$ emission for all non-tropical forest fires is $68 \mathrm{Mt} \mathrm{CO}$ per year. A concentration of as little as $400 \mathrm{ppm}(0.04 \%) \mathrm{CO}$ in the air can be fatal. The levels of normal carboxyhemoglobin in an average person are less than $5 \%$, whereas cigarette smokers (two packs/day) may have to levels up to $9 \%$ (Delaney et al., 2001).

$\mathrm{CO}$ can direct observe from space due to its strong absorption properties in the thermal infrared $(4.7 \mu \mathrm{m})$ and in the solar shortwave infrared $(2.3 \mu \mathrm{m})$. Since past decade, there are a number of satellite instruments available, in order to measure troposheric CO globally, including Measurements Of Pollution In The Troposphere (MOPITT) [Emmons et al., 2007, 2009], SCanning Imaging Absorption spectroMeter for Atmospheric CartograpHY (SCIAMACHY) [Bovensmann et al., 1999; Burrows et al., 1995], AIRS (McMillan et al., 2005, 2008), Atmospheric Chemistry Experiment-Fourier Transform Spectrometer (ACE-FTS) [Clerbaux et al., 2005, 2008], Technology Experiment Satellite (TES) [Lopez et al., 2008; Luo et al., 2007], and Infrared Atmospheric Sounding Interferometer (IASI) [Fortems-Cheiney et al., 2009; Turquety et al., 2009]. These satellite data overcome the problem faced by in-situ measurements and commercial aircraft (Nedelec et al., 2003).

The AIRS CO retrievals shown here were produced as operational products by the NASA Goddard Earth Sciences (GES) Data Information and Service Center (DISC) have been employed in many studies. The first observation of tropospheric $\mathrm{CO}$ was presented by McMillan et al. (2005) during track the impact of major south American fire 22-29 September 2002, and the daily global maps showed the advection of a large CO plume with forward trajectories conforming to long-rang transport, from biomass burning, as far east as the southern Indian Ocean. The comparisons to in-situ aircraft profiles indicate AIRS CO retrievals at 500 mbar are accurate to at least $10 \%$ in the northern hemisphere and 
approaching the $15 \%$ accuracy target set by per-launch simulations. McMillan et al. (2007) investigated the wealth of AIRS CO retrievals information contained more than five years, and improved decisively both the characterization of the vertical distribution of $\mathrm{CO}$ information in the AIRS retrievals and the sensitivity to the lower tropospheric CO. The analysis showed the capabilities of AIRS see Megacities and large-scale interannual variations in emissions linked to El Nino.

Warner et al. (2007), Kopacz et al. (2010) compared AIRS retrievals against MOPITT for AIRS validation of global CO mixing ratios at 500 mbar. Furthermore, presented are the comparisons of the satellite profiles with in-situ profiles. Because of the simultaneous measurements of troposphere $\mathrm{CO}$ from instruments, the comparison and a cross reference are necessary to understand these two data sets and their effects to the scientific conclusions developed from them. Yurganov et al. (2010) compared troposphere CO profiles from AIRS against Atmospheric Emitted Radiance Interferometer (AERI) over North America, the Northern Hemisphere (NH) mid-latitudes, and over the tropics for the period 2002-2009, and there is a good agreement between AIRS and AERI in the surface and total column measurements. They showed that the three months temporal of $\mathrm{CO}$ burden minima between the $\mathrm{NH}$ mid-latitudes and tropics could effect from transport of lower $\mathrm{CO}$ burdens from south to north. In addition, tropics contain about half of the global air mass and $\mathrm{CO}$ burden anomaly are higher there than in the $\mathrm{NH}$.

\section{Study area}

The study area is Peninsular Malaysia, which is located between $1^{\circ}$ to $7^{\circ}$ latitudes north and $99^{\circ}$ to $105^{\circ}$ longitudes east, south of Thailand, north of Singapore and east of the Indonesian island of Sumatra. An area (Fig. 1), covering $3.575 \times 105 \mathrm{~km}^{2}$, with a center at Pahang $\left(102^{\circ} \mathrm{E}\right.$ and $4^{\circ} \mathrm{N}$ ) was selected for this study. The central dimensions of the study domain are 550 $\mathrm{km}$ E-W and $650 \mathrm{~km}$ N-S. The Titiwangsa Mountain is a range from the Malaysia-Thai border in the north running approximately south-southeast over a distance of $480 \mathrm{~km}$ forms the backbone of the Peninsular and separating the western part from the western part. Surrounding the central high regions are the coastal lowlands (Suhaila \& Jemain, 2007).

As a characteristic for a humid tropical climate, in Peninsular Malaysia the weather is warm and humid throughout the year with temperatures ranging from $21^{\circ} \mathrm{C}$ to $32^{\circ} \mathrm{C}$. In Malaysia never experienced the excessive day temperatures which are found in continental tropical areas, very rarely been recorded air temperature of $38^{\circ} \mathrm{C}$, the days are oftentimes hot and the nights are reasonably cool everywhere (Dasimah, 2009). The highest average temperatures are at April-May and July-August in most places, and the lowest average monthly temperatures are at November-January. Although the variations of the spatial and seasonal temperature are relatively small, they are, nevertheless, equitably definite in some respects and are deserving mention (Shahruddin \& Mohamed, 2005). There is a definite variation of monthly mean temperature coincided with the monsoons, the annual fluctuations of roughly $1.5-2^{\circ} \mathrm{C}$. The monsoons significantly affect the climate of Peninsular Malaysia. It experiences two rainy seasons throughout the year associated with the Northeast Monsoon (NEM) from November to February and the Southwest Monsoon (SWM) from May to August (Wong at el., 2009).

During the inter-monsoon months (usually occur in April and October), the wind light and variable, and thunderstorms develop causing Substantial rainfall in each of the two transition periods, especially in the west coast states. Monsoon changes as well as the effects 
of topography are the main factors that affect the rainfall distributions. The monsoon rainfalls form $81 \%$ of annual rain that falls in the entire Peninsular Malaysia, which was estimated approximately $2300 \mathrm{~mm}$ (Suhaila \& Jemain, 2009). Maximum rainfall is occurred near the end of the year during the early NEM in most of the areas, while second maximum rainfall during the intermonsoon months (April or May). The high intensity rainfall is absolutely absent during the SWM period except in the west coastal stations. The lowest monthly rainfall occurs in February, and the highest monthly rainfall in December (Varikoden et al., 2010).

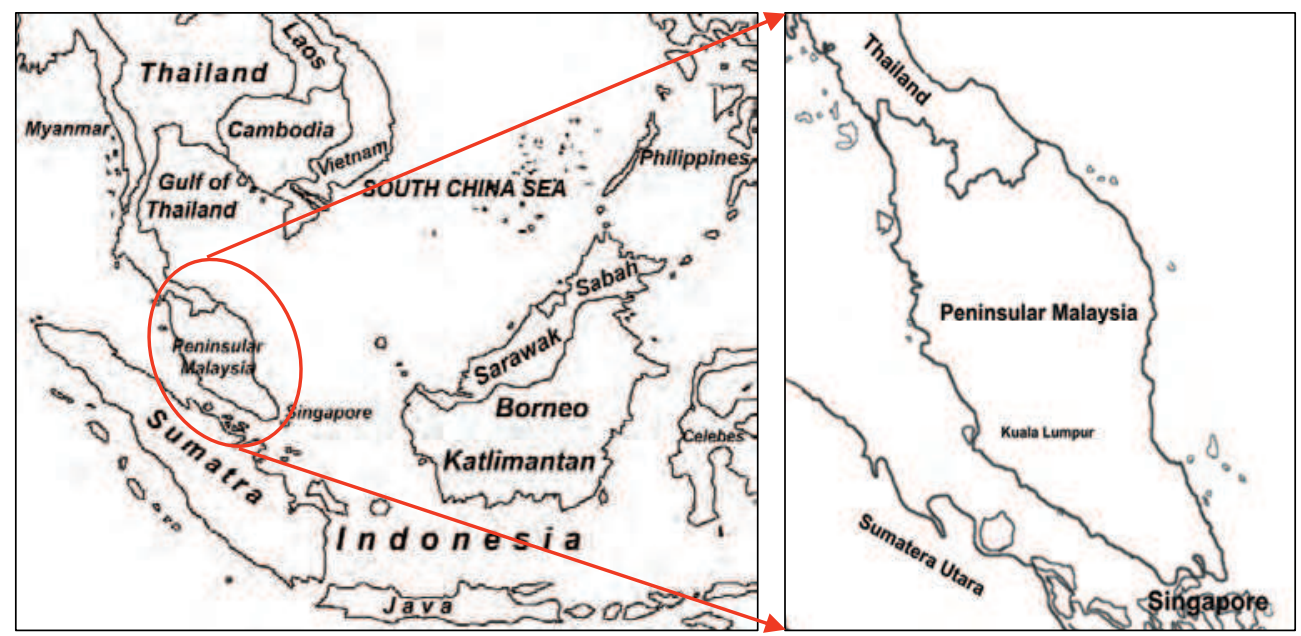

Fig. 1. The geographical feature of study area.

\section{Acquisition and specification}

The first new generation of meteorological advanced sounders for operational and research use was AIRS, one of several instruments onboard the EOS Aqua spacecraft launched May 4, 2002. AIRS instrument and its two companions microwave instruments, the Advanced Microwave Sounding Unit (AMSU) and the Humidity Sounder for Brazil (HSB), form the integrated atmospheric sounding system are characterizing and observing the entire atmospheric column from the surface to the top of the atmosphere in terms of temperature and surface emissivity, cloud amount and height, atmospheric temperature and humidity profiles and the spectral outgoing infrared radiation (Fishbein et al., 2007). The Aqua spacecraft coverage is pole-to-pole, and covers the globe two times a day, at orbit is polar sun-synchronous with a nominal altitude of $705 \mathrm{~km}$ (438 miles) and an orbital period of 98.8 minutes. The platform equatorial crossing local times are 1:30 in the afternoon (ascending) and 1:30 in the morning (descending). The respect cycle period is 233 orbits (16 days) with a ground track repeatability of $+/-20 \mathrm{~km}$ (Aumann et al., 2003).

The AIRS is a "facility" instrument developed by NASA as an experimental demonstration of the benefits of high resolution infrared spectra to science investigations and advanced technology for remote sensing (Pagano et al., 2006). The capability of AIRS/AMSU/HSB to supply simultaneous observations of the Earth's atmospheric temperature, land surface 
temperature, and ocean surface temperature, water vapor, cloud amount and cloud height, albedo, as well as new research products of greenhouse gas and aerosols, makes AIRS the most important EOS instrument for investigating several interdisciplinary issues to be addressed in Earth science (Pagano et al., 2003). The instruments suite was designed to measure the Earth atmospheric water vapor to an accuracy of $10 \%$ in $2 \mathrm{~km}$ layers in the lower troposphere and an accuracy of $50 \%$ in the upper troposphere. It also provides atmosphere temperature profiles with $1 \mathrm{~K} / \mathrm{km}$ accuracy in the troposphere and $1 \mathrm{~K} / 4 \mathrm{~km}$ layer in the stratosphere up to an altitude of $40 \mathrm{~km}$. Also, provides integrated column burden for several trace gases (Chahine et al., 2006). Figure 2.1 shows the scanning geometry of AIRS and AMSU-A.

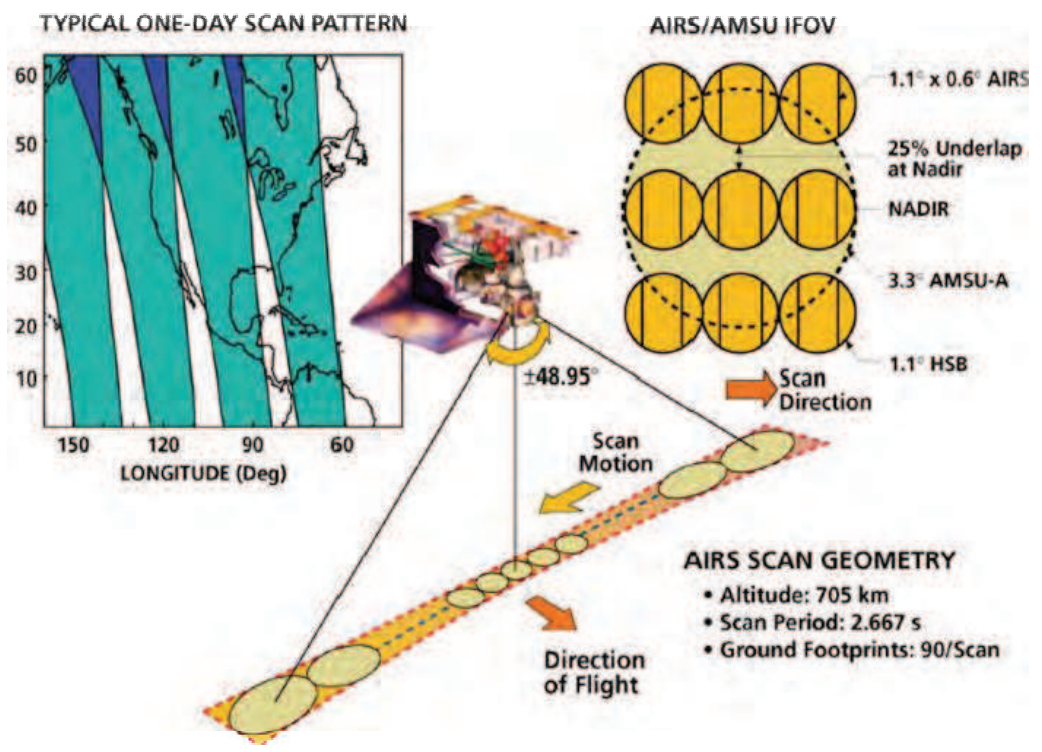

Fig. 2. Schematic showing the AIRS and AMSU scan geometrics [Jason, 2008].

AIRS is a continuously operating cross-track scanning sounder, consisting of a telescope that feeds a scale spectrometer. The AIRS instrument views the atmospheric infrared spectrum in 2378 channels with a nominal spectral resolving power $N \Delta \lambda$ ranging from 1086 to 1570 covering more than $95 \%$ of the earth surface and returning about three million spectra daily, in the 3.74-4.61 $\mu \mathrm{m}, 6.20-8.22 \mu \mathrm{m}$ and 8.8-15.4 $\mu \mathrm{m}$ infrared wavebands at a nominal spectral resolution, also includes four visible/near-IR (Vis/NIR) channels between 0.40 and $0.94 \mu \mathrm{m}$, with a 2.3-km FOV (Strow et al., 2003).

The AIRS Science Processing System (SPS) is a set of programs, or Product Generation Executives (PGEs), utilize to process AIRS Science Data. These PGEs process raw, AIRS Visible (VIS), low level AIRS Infrared (AIRS), AMSU, and HSB instrument data to acquire temperature and humidity profiles. There are four distinct processing phases for processing the AIRS PGEs: Level 1A, Level 1B, Level 2 and Level 3 (Fishbein et al., 2007). Level 1A, Level 1B and Level 2 produce 240 granules of different products every day. Each product granule contains six minutes of data (Ye et al., 2007). 
The L3 data are created from the L2 data product by binning them in $1^{\circ} \times 1^{\circ}$ grids. Level 3 products are statistical summaries of geophysical parameters that have been temporally aggregated and spatially re-sampled from lower level data products (e.g., Level 2 data) (Pagano et al., 2006). There are three AIRS Level 3 data products separately derived from Microwave-Only (MW-Only) retrievals and combined Infrared/Microwave (IR/MW) retrievals: daily, weekly and monthly as summarized in Table 1 Each product provides separate ascending (daytime) and descending (nighttime) binned data sets. When there is no coverage for that day, the daily Level 3 products will have gores between the satellite paths. The weekly Level 3 products may have missing data because of data dropouts. Monthly Level 3 products will probably contain complete global coverage with little missing data and without gores (Aumann et al., 2001).

\begin{tabular}{|c|c|c|}
\hline Data Set & Short Name & Granule Size \\
\hline L1B AMSU-A radiances & AIRABRAD & $0.5 \mathrm{MB}$ \\
\hline L1B HSB radiances & AIRHBRAD & $1.7 \mathrm{MB}$ \\
\hline L1B AIRS radiances & AIRIBRAD & $56 \mathrm{MB}$ \\
\hline L1B VIS radiances & AIRVBRAD & $21 \mathrm{MB}$ \\
\hline L1B AIRS QA & AIRIBQAP & $5.6 \mathrm{MB}$ \\
\hline L1B VIS QA & AIRVBQAP & $1.1 \mathrm{MB}$ \\
\hline L2 Cloud-cleared radiances & AIRI2CCF & $10 \mathrm{MB}$ \\
\hline L2 Standard Product & AIRX2RET & $5.4 \mathrm{MB}$ \\
\hline L2 Support Product & AIRX2SUP & $20 \mathrm{MB}$ \\
\hline L3 standard daily product & AIRX3STD & $\sim 70 \mathrm{MB}$ \\
\hline L3 8-day standard product & AIRX3ST8 & $\sim 103 \mathrm{MB}$ \\
\hline L3 monthly standard product & AIRX3STM & $\sim 105 \mathrm{MB}$ \\
\hline
\end{tabular}

Table 1. Level 1, Level 2 and Level 3 data set products. (Jason, 2008).

\section{Materials and methods}

The study has been carried out for daily [six-day (12-23) August 2005 and six-day (13-24) August 2007], and monthly 2009 data. In order to evaluate and analysis the impact of Indonesia forest fire on $\mathrm{CO}$ distribution, and the monthly $\mathrm{CO}$ distributions in the study area. Five dispersed stations were selected across Peninsular Malaysia: Subang, Penang, Kuantan, Johor, and Kota Bharu to compare the daily data from August 2005 and August 2007. Results from the analysis of the retrieved for the CO obtained from AIRS ascending Level 3 daily standard (AIR×3STD) and Monthly standard product (AIRX3STM) data. Generally, twelve daily and twelve monthly L3 ascending granules were downloading to obtain the desired output. Extract the (AIR×3STD) and (AIRX3STM) product's files from the Satellite using the AIRS website, and saves in HDF-EOS4 files; this is a convenient file extension that can be easily extracted data from it and arrange in table using MS Excel.

Data including the corresponding location and time along the satellite track in a HDF (Hierarchical Data Format) format on monthly basis. Map of the study area was conducted by using Photoshop CS and SigmaPlot 11.0 software to analyze CO data distribution along the study period. To better assess the impacts and distribution of $\mathrm{CO}$ above Peninsular 
Malaysia, the maps of $\mathrm{CO}$ were generated by using Kriging interpolation technique for the daily (August 2005 and 2007), and monthly 2009. The CO data were obtained from $1^{\mathrm{o*}} 1^{\circ}$ degree (latitude $\times$ longitude) spatial resolution ascending orbits.

\section{Data analysis and results}

\subsection{Daily peninsular Malaysia CO maps and comparisons}

The skies over Peninsular Malaysia were noticeably hazier than normal on mid-August 2005. In this section, we examine the impact of one smoke transport event on CO levels in Peninsular Malaysia. The elevated levels of $\mathrm{CO}$ found in smoke plumes from incomplete combustion of forest fires can lead to important further $\mathrm{CO}$ production downwind of the fires. To better assess the influences of forest fires and the transport smoke filled air mass on the local air quality in Peninsular Malaysia. We examined the data from AIRS for two different periods daily (12-23) August 2005 and (13-24) August 2007.

The six maps in Fig. 3 (12-23) August 2005 illustrate the extent of AIRS Daily coverage of Total column $\mathrm{CO}$, the nominal peak of AIRS vertical sensitivity and the magnitude of the variations in atmospheric CO over Peninsular Malaysia. It observed an elevation in the CO values higher than normal rates during the period from mid-July to mid-August 2005 in Malaysia (Rajab et al., 2009).

The AIRS data in Fig. 3 indicate numerous fires in the regions of enhanced $\mathrm{CO}$ over Malaysia. In Indonesia, the fire counts peaked on 13-15 August in Sumatra (DOE, 2009). From Fig. 3 (12, 14 and 16 August), can see the advection of the CO plume from Sumatra, Indonesia, to Peninsular Malaysia. The CO Pollution for this event was characterized the increase in $\mathrm{CO}$ by $60 \%$ in the northern region (uppers the latitude 4, e.g. Penang and Kota Bahru), 35\% in the central and east coast district (e.g. Kuala Lumpur and Kuantan), and 20\% in the southern area (e.g. Johor). Plainly evident the $\mathrm{CO}$ total column values are high in 12 August, increase to be highest in 14 August, and a gradual decrease of $\mathrm{CO}$ values after 16 with a reduction impact of the forest fire, compared to previous days (DOE, 2005). The highest value was when the hazy conditions reached its peak on 12 August over Selangor $\left(2.68 \times 10^{18}\right.$ molecules $\left./ \mathrm{cm}^{2}\right)$.

Fig. $3(18,21$ and 23), while the CO value is still high in the Sumatra, shows the gradual decrease of the concentration of $\mathrm{CO}$ in most areas in coinciding with the declaration of the end of the hazy conditions. The lowest value of $\mathrm{CO}$ was on 23 August over Terengganu $\left(1.75 \times 10^{18}\right.$ molecules $\left./ \mathrm{cm}^{2}\right)$.

From Fig. 4, illustrate the CO values from 13 to 24 August 2007, were normal circumstances in the absence of any event can observe the highest CO total column over central areas (e.g. Selangor and Negeri Sembilan), Penang and Johor. These regions represent biomass burning sources, long-range transport and industrial/domestic fuel sources. Enhanced CO values in Selangor on 13 August $\left(1.95 \times 10^{18}\right.$ molecules $\left./ \mathrm{cm}^{2}\right)$. The greater draw down of CO total column occurs over pristine marine environment in the north east coast of Terengganu and in the Inland region of north Kelantan $\left(1.56 \times 10^{18}\right.$ molecules $\left./ \mathrm{cm}^{2}\right)$.

To illustrate the biases between the two data sets, which are caused by biomass burning, the daily August 2005 and 2007 zonal averaged CO total column is showed in Fig. 5. In Fig. 5, a daily series graph of CO August 2005 (solid line) compared to daily CO August 2007 (dots line) from observed AIRS for five stations; kota Bahru, Penang, Kuantan, Subang, and Johor, where the day is on the $\mathrm{x}$-axis and CO total column (molecules $/ \mathrm{cm}^{2}$ ) on the y-axis. It can be seen clearly, in all the stations the daily CO concentration on August 2005 is higher than August 2007. There is a clear difference between two lines, especially in 14 August when the 
impacts of forest fire up to a maximum. The discrepancies become less after 17 August with a lower impact of fires. In general, south to north the $\mathrm{CO}$ values differences are larger than West to East between two lines over study areas. The largest differences are in the north regions (uppers the latitude 4 ).

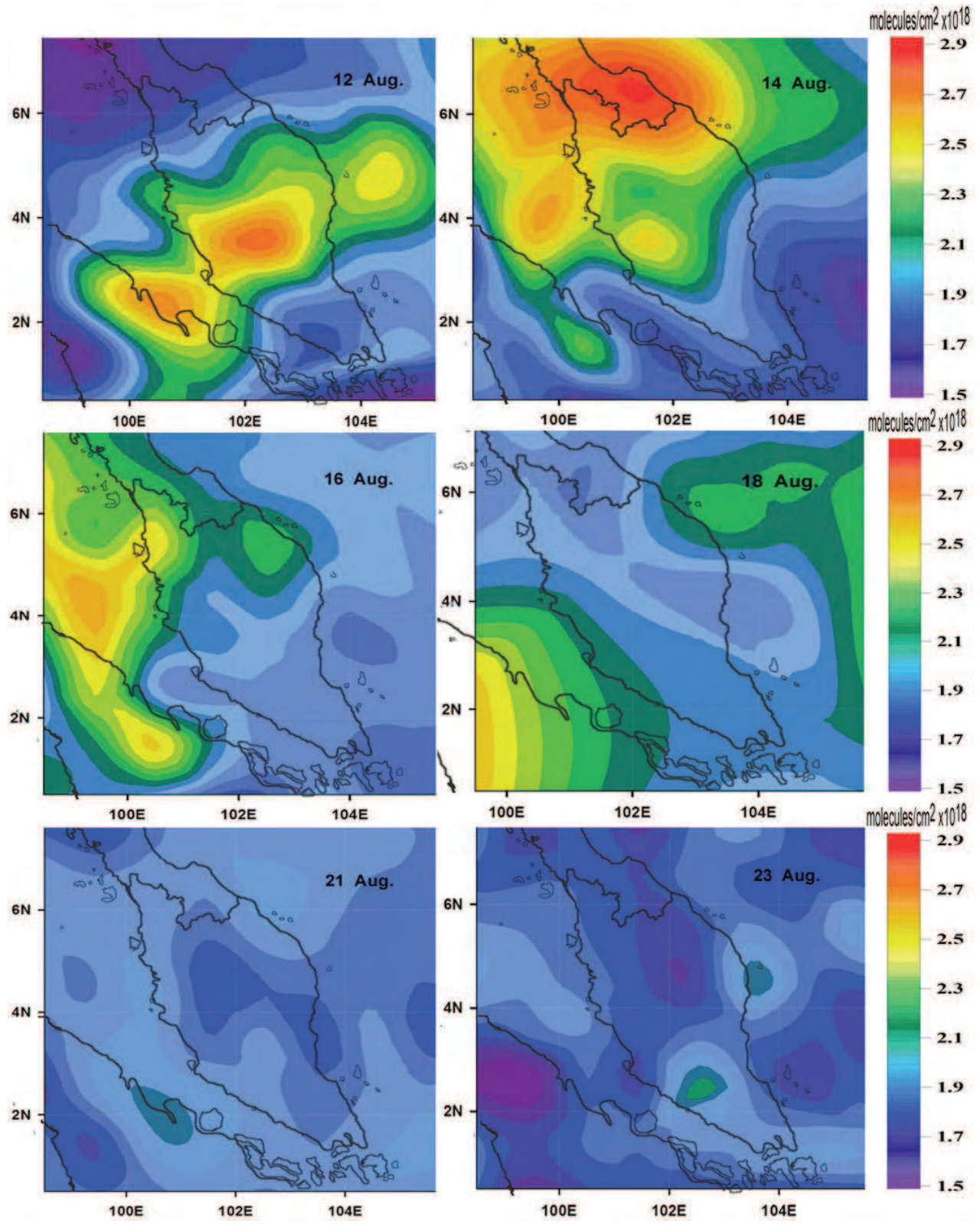

Fig. 3. CO total column (molecules/ $\mathrm{cm}^{2}$ ) for daily (12-23) August 2005 in Peninsular Malaysia. 

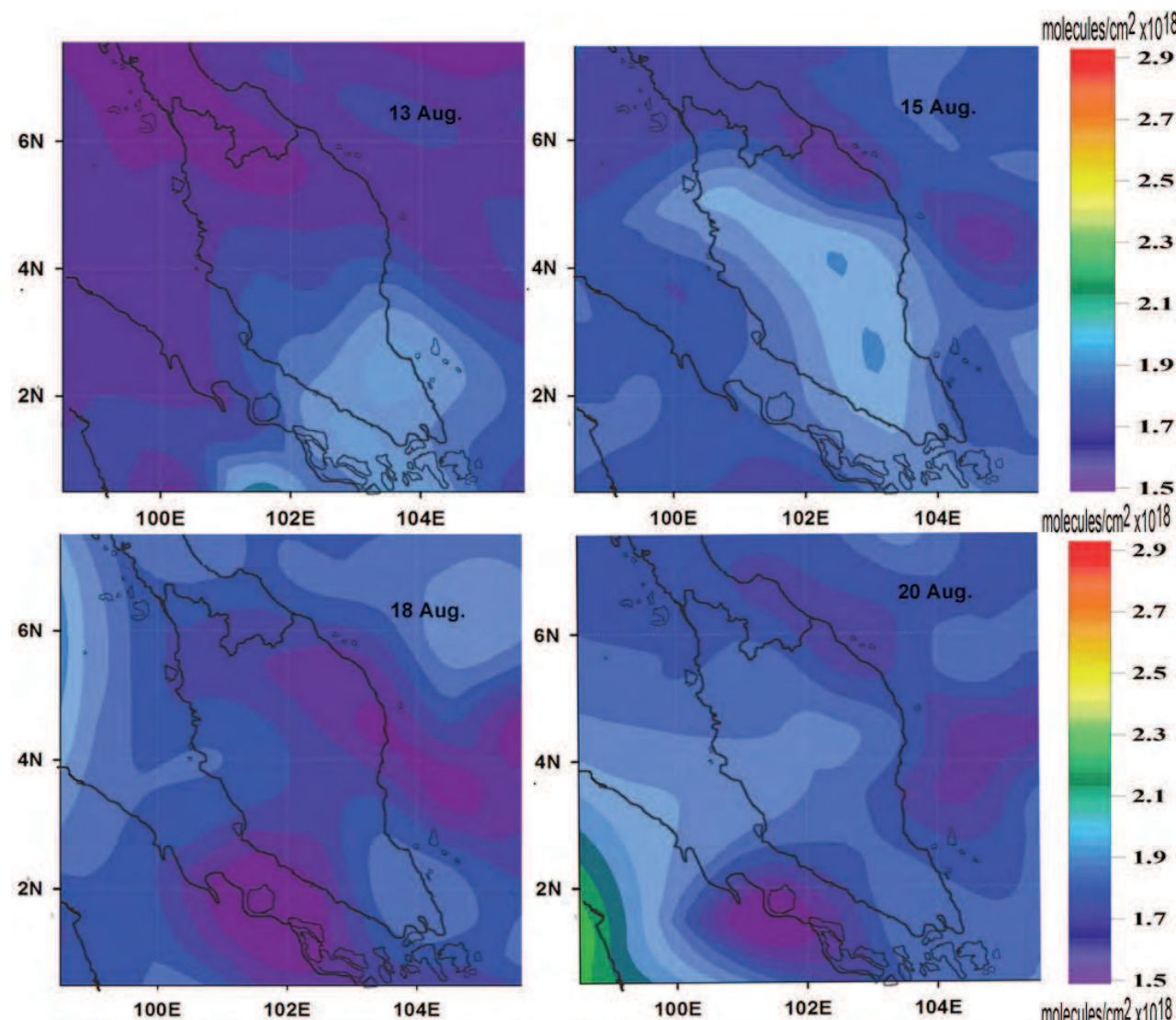

molecules $/ \mathrm{cm} 2 \times 1018$
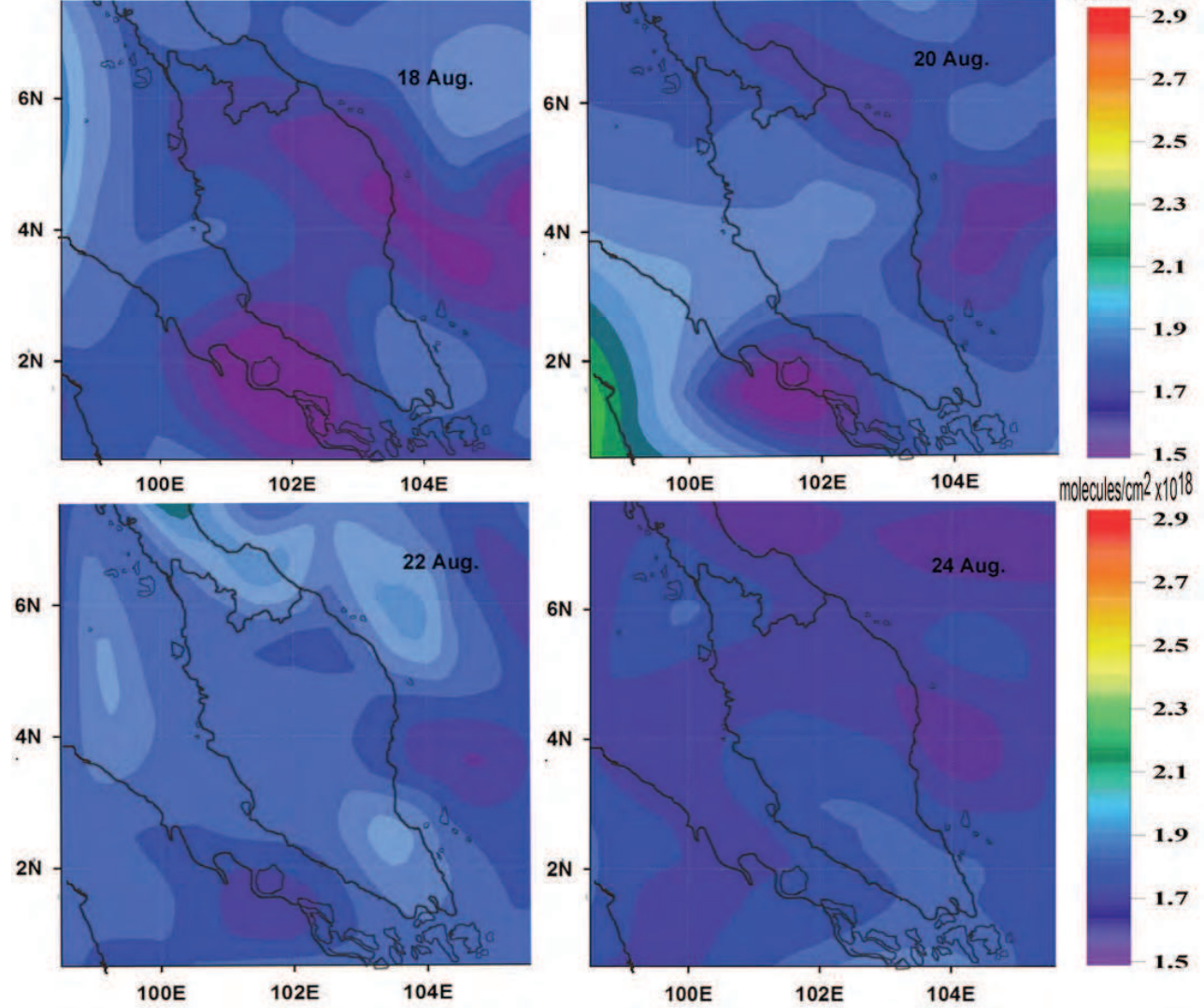

Fig. 4. CO total column (molecules/ $\mathrm{cm}^{2}$ ) for daily (13-24) August 2007 in Peninsular Malaysia. 
Investigation on the Carbon Monoxide Pollution over Peninsular

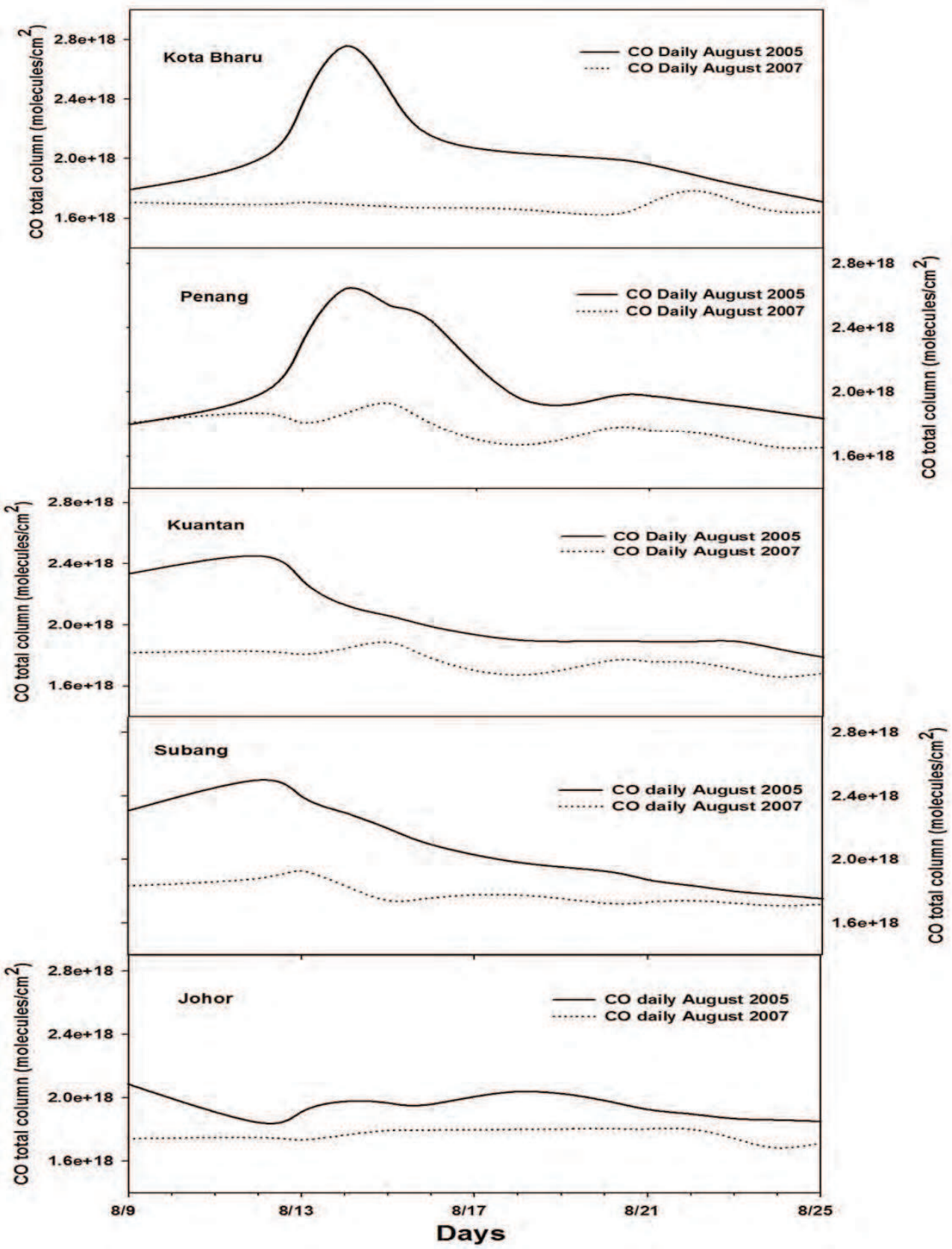

Fig. 5. The CO total column August 2005 (solid line) compared to daily CO total column August 2007 (dots line) from observed AIRS for five stations; Kota Bahru, Penang, Kuantan, Subang, and Johor. 


\subsection{Monthly peninsular Malaysia CO maps for 2009}

The retrieved CO total column amount (CO_total_column_A) Level-3 monthly (AIRX3STM) $1^{\circ} \times 1^{\circ}$ spatial resolution used for mapping $\mathrm{CO}$ for 2009 . Based on the combination of rich local sources of $\mathrm{CO}$ along with the transport of additional significant amount of pollution from Siberia and northeast Asia brings in the beginning of the northeast monsoon led to increase the values of CO at early dry season (Pochanart et al., 2004), that are shown in Fig. 6 for dry season.

Plainly evident the impact of peatland fires in several areas in Sumatra, Indonesia, on the values of $\mathrm{CO}$ in the north and central of Peninsular Malaysia during January, with continuing its impact on the central and southern regions during February. Unusually, there was a decrease in the values of $\mathrm{CO}$ at the end of the dry season during March-April due to unexpected reasonable rainfall during this period throughout the Peninsular Malaysia (Malaysian Meteorological Department, 2009). The highest value of CO in dry season was $\left(2.19 \times 10^{18}\right.$ molecules $\left./ \mathrm{cm}^{2}\right)$ over Selangor on January $\left\{\right.$ at $101.5^{\circ} \times 3.5^{\circ}$, red pixels $\}$, while the less value was $\left(1.75 \times 10^{18}\right.$ molecules $\left./ \mathrm{cm}^{2}\right)$ over Perak on April \{at $101.5^{\circ} \times 5.5^{\circ}$, violet pixels\}. The strong effects of regional biomass burning during the dry season, a regular annual occurrence in January to April, makes it extremely difficult to detect any evidence of the long-range transport of air pollution to Southeast Asia from other regions (Pochanart et al., 2004).

Normally, in the late dry season, large regional biomasses burning occur and the impact of air masses pollution transport has significant from the western Asia, Middle East and East Asia (Pochanart et al., 2003). The El-Niño episodes can lead to immense displacement of rainfall regions in the tropics, bringing torrential rain to otherwise arid regions and drought to vast areas. Uniform warming prevail all the regions in Malaysia during an El-Niño event, especially during the November to March (Cheang, 1993). When El-Niño has a drought effect, there will be large biomass burning and increase CO emission (McMillan et al., 2007).

Fig. 7 shows that the $\mathrm{CO}$ have low value in the north regions, upper the latitude 5, and low to moderate in the rest of regions during the early wet season (May-July), due to the high levels of moisture and incident solar irradiation causes the production of the $\mathrm{OH}$, the primary oxidizer for $\mathrm{CO}$. When $\mathrm{OH}$ abundance is near a maximum; $\mathrm{CO}$ is near minimum (McMillan et al., 2007). Considerable values of $\mathrm{OH}$ are sufficient to provide significant spoilage rates of trace gases in the haze outflow, outputting for example in a CO lifetime of only $\sim 15$ days near the surface. The subtle differences peak of biomass burning indicate differences in transport patterns as well as differences in rainfall patterns across the region, the enhanced CO emission correlates with occasions of less rainfall (McMillan et al., 2007). Additionally, the lack of rain results in long carbonaceous lifetimes, this lengthens the time during which oxidation reactions can take place (Rasch et al., 2001).

In the late wet season (August-October), observed moderate value in the north regions, upper the latitude 5, while slightly high to high values in the rest of regions due to the impact of peatland fires from Sumatra and transboundary pollution which was aggravated by hot weather conditions (DOE, 2009). The highest value was $\left(2.153 \times 10^{18}\right.$ molecules $\left./ \mathrm{cm}^{2}\right)$ over Johor on October $\left\{\right.$ at $103.5^{\circ} \times 1.5^{\circ}$, red pixels\}, while the less value was $\left(1.702 \times 10^{18}\right.$ molecules $/ \mathrm{cm}^{2}$ ) over Perak on June $\left\{\right.$ at $101.5^{\circ} \times 5.5^{\circ}$, violet pixels\} during the wet season.

During the summer monsoon (wet season) May - October, the marine air masses from the middle and low latitudes of the Southern Hemispheric Indian Ocean are dominated continental Southeast Asia. These marine air masses carry small to moderate amounts of air pollution to southwest Asia. In addition, less regional biomass burning occurred and 
the impact of air masses is less significant from the Pacific and Indian Oceans (Pochanart et al., 2003).
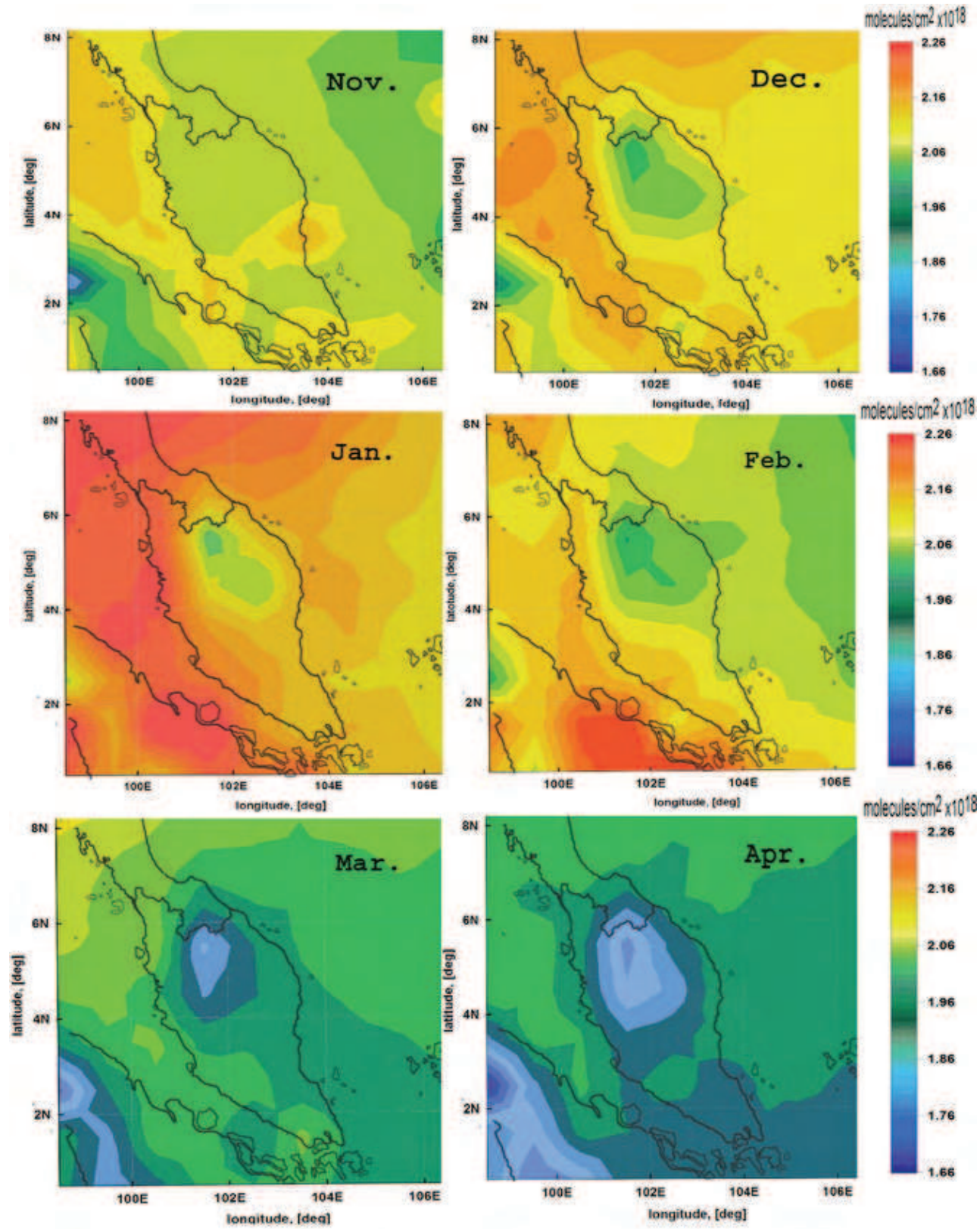

Fig. 6. AIRS monthly coverage retrieved total column carbon monoxide (CO) for dry season [November to April] 2009. 

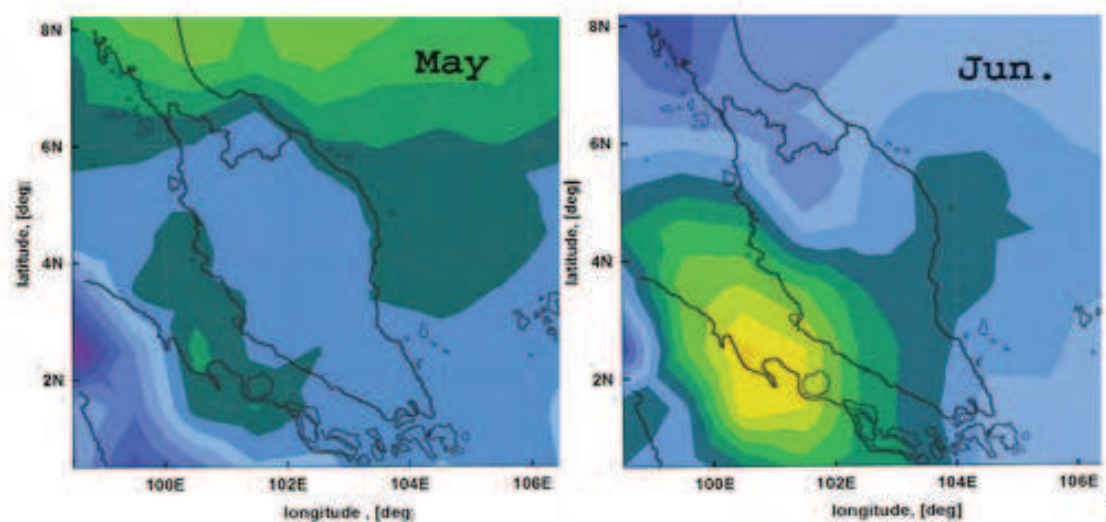

moleaves $\operatorname{con} 2 \times 1018$
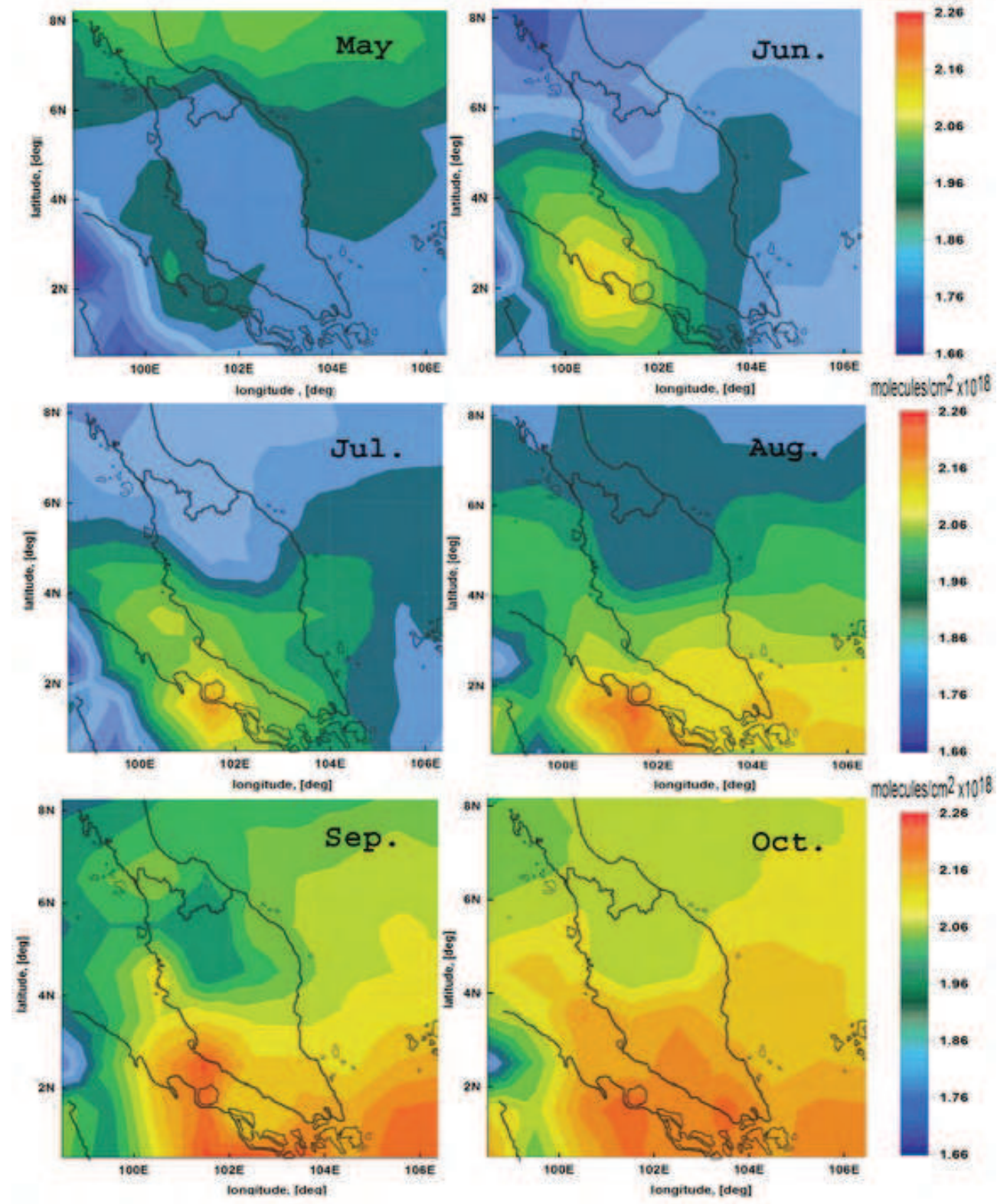

Fig. 7. AIRS monthly coverage retrieved total column carbon monoxide (CO) for wet season [May to October] 2009.

In short, observed the highest values of $\mathrm{CO}$ occurred when biomass burning during dry season, and also over the industrial and congested urban zones (it is the most abundant 
pollutant in urban atmosphere and very stable, having an average lifetime of about two months) where the main source of emission was vehicles which contributed to 95 percent of CO emission load in Malaysia during 2009 (DOE, 2009; Kopacz, et al., 2010). A greater draw down of the $\mathrm{CO}$ occurs over the pristine continental environment in the northeast region regions on June at Perak $\left(101.5^{\circ} \times 5^{\circ}\right)$ during wet season. This was due to lack of sources CO as well as the direct influence of south westerly wind, which remove polluting gases continuously (CO slightly lighter than air) (Jasim et al., 2010). Furthermore, the rain is a great cleanser of the atmosphere so the (Hoskins, 2001).

In addition, the $\mathrm{CO}$ values were higher in the central and southern regions than the rest of regions throughout the year because there are many sources, crowded cities, and more affected by the peatland fires in Sumatra. Can be seen also the impact of El-Nino on CO values during June-August from the unusually high values of $\mathrm{CO}$ in this period, especially in southern region.

\section{Conclusion}

This chapter has reviewed the impact of the $\mathrm{CO}$ pollutants by long-range transport from Sumatra, Indonesia, forest fires during August 2005, and monthly distributions 2009 in Peninsular Malaysia. While an immense amount about these issues has been analyzed over the forest fires, there are still many regional sources making it extremely difficult to detect it. The monsoon regimes provide the main climatological controls on the air pollution in Southeast Asia. During the winter monsoon, cold surges originating from Siberia and northeast Asia brings a significant amount of pollution to Southeast Asia while crossing through the heavily-polluted regions of East Asia and caused the heavy rain falls. During the summer monsoon, the impact of air pollution transport is less significant due to the less regional biomass burning occurred, and the marine air masses carry small to moderate amounts of air pollution to southwest Asia from the Pacific and Indian Oceans.

As demonstrated here, AIRS' daily views of atmosphere CO total column across the study area enables detailed analyses of both the spatial and temporal variations in emissions and the visualization of subsequent transport. Focusing on a major Sumatra, Indonesia, fire event, the AIRS daily Peninsular Malaysia maps show the advection of a large CO plume with forward trajectories confirming long-range transport as far as north east as Peninsular Malaysia. The daily maps also distinctly identified the plainly evidence with high values of $\mathrm{CO}$ occurred when biomass burning from Indonesia's forest fires reached its peak.

The local CO maximum was in a region experienced extensive the intense fires. The daily maps shows characterized elevated $\mathrm{CO}$ values by $60 \%$ in the northern region (uppers the latitude 4 ), 35\% in the central and east coast district, and $20 \%$ in the southern area. The highest value was when the hazy conditions reached its peak on 12 August over Selangor $(2.68 \times 1018$ molecules/cm2). And the lowest value of $\mathrm{CO}$ was on 23 August over Terengganu $\left(1.75 \times 10^{18}\right.$ molecules $\left./ \mathrm{cm}^{2}\right)$.

From the daily maps in August 2007 for normal circumstances, the highest CO values occurred above the industrial and congested urban zones $\left(1.95 \times 10^{18}\right.$ molecules $\left./ \mathrm{cm}^{2}\right)$. The greater draw down of $\mathrm{CO}$ total column occurs over pristine marine environment in the north east coast of Terengganu and in the Inland region of north Kelantan $\left(1.56 \times 10^{18}\right.$ molecules $/ \mathrm{cm}^{2}$ ).

It can be seen clearly from the comparison between the daily August 2005 and 2007; in all the stations, the daily CO concentration on August 2005 is higher than August 2007. There is 
a clear large difference between two lines, especially in 14 August when the impacts of forest fire up to a maximum. The discrepancies become less after 17 August coincides with a reduction effect of the forest fires.

The AIRS/Aqua Level 3 Monthly gridded product (AIRX3STD) $1 \times 1^{\circ}$ spatial resolution, Version 5 data using AIRS IR and AMSU, without-HSB, employed to investigate a monthly distribution map of $\mathrm{CO}$ total column over study area for 2009. The high $\mathrm{CO}$ values observed during the dry season, due to the strong influences of regional biomass burning, a regular annual occurrence in January to April, and coupled with the significant impacts of air mass pollution transport from the East Asia to by winter monsoon. The highest value was $\left(2.19 \times 10^{18}\right.$ molecules $\left./ \mathrm{cm}^{2}\right)$ over Selangor, while the less value was $\left(1.75 \times 10^{18}\right.$ molecules $/ \mathrm{cm}^{2}$ ) over Perak.

The low CO values prevail on the wet season due to the less biomass burning occurred, and the marine air masses from the middle and low latitudes of the Southern Hemispheric Indian Ocean carried small to moderate amounts of air pollution. Furthermore, the high levels of moisture and incident solar irradiation lead to the production of the $\mathrm{OH}$, the primary oxidizer for $\mathrm{CO}$. The $\mathrm{OH}$ abundance is near a maximum; $\mathrm{CO}$ is near minimum. The highest value was $\left(2.153 \times 10^{18}\right.$ molecules $\left./ \mathrm{cm}^{2}\right)$ over Johor.

In short, the highest $\mathrm{CO}$ values was during biomass burning occurred in dry season, and over industrial and congested urban zones. The cleaner areas and the less $\mathrm{CO}$ value areas throughout the year in Peninsular Malaysia was Perak at (long. $101.5^{\circ} \times$ lat. $3.5^{\circ}$ ), where the green lands, vast forest and lack sources of pollution.

This study has provided evidence for the impact of remote $\mathrm{CO}$ total column emissions and forest fire on $\mathrm{CO}$ pollution levels above study area using satellite data. Furthermore, it enhanced our knowledge on AIRS detection of $\mathrm{CO}$ emission from forest fire, the utility and accuracy of remotely sensed atmospheric CO total column and abundances from AIRS. Satellite measurements are able to measure the increase of atmospheric $\mathrm{CO}$ values over different areas. $\mathrm{CO}$ maps from AIRS will lead to a more understanding of the CO budgets.

\section{Acknowledgement}

The authors gratefully acknowledge the financial support from the Relationship between Heavy Rain, Flash Floods and Central Pressure in Malaysia Grant, account number: 1001/PFIZIK/811152 and USM-RU-PRGS Grant, account number:1001/PFIZIK/841029. We would like to thank the technical staff who participated in this study. Thanks are also extended to USM for support and encouragement.

\section{References}

Andreae, M. O. \& Merlet, P. (2001). Emission of Trace Gases and Aerosols From Biomass Burning. Global Biogeochemical Cycles, Vol.15, pp.955-966.

Aumann, H. H., Goldberg, M., Mcmillin, L., Rosenkranz, P., Staelin, D., Strow, L. \& Susskind, J. (2001). AIRS-Team Retrieval For Core Products and Geophysical Parameters. In AIRS Team - NASA (Ed., Jet Propulsion Laboratory.

Aumann, H. H., Chahine, M. T., Gautier, C., Goldberg, M. D., Kalnay, E., McMillin, L. M., Revercomb, H., Rosenkranz, P. W., Smith, W. L., Staelin, D. H., Strow, L. L. \& Susskind, J. (2003). AIRS/AMSU/HSB on the Aqua mission: Design, Science Objectives, Data Products, and Processing Systems. IEEE Transaction On Geoscience And Remote Sensing, Vol.41, No.2, pp.253-264. 
Bovensmann, H., Burrows, J. P., Buchwitz, M., Frerick, J., Noël, S., Rozanov, V. V., Chance, K. V. \& Goede, A. P. H. (1999). SCIAMACHY - Mission Objectives and Measurement Modes. Atmospheric Chemistry and Physics, Vol.56, pp.127-150.

Buchwitz, M., Khlystova, I., Bovensmann, H. \& Burrows, J. P. (2007). Three Years of Global Carbon Monoxide From SCIAMACHY: Comparison With MOPITT and First Results Related To The Detection of Enhanced CO Over Cities. Atmospheric Chemistry and Physics, Vol.7, pp.2399-2411.

Buchwitz, M., de Beek, R., Noël, S., Burrows, J. P., Bovensmann, H., Schneising, O., Khlystova, I., Bruns, M., Bremer, H., Bergamaschi, P., Körner, S. \& Heimann, M. (2006). Atmospheric Carbon Gases Retrieved From SCIAMACHY By WFM-DOAS: Version $0.5 \mathrm{CO}$ and $\mathrm{CH}_{4}$ and Impact of Calibration Improvements on $\mathrm{CO}_{2}$ Retrieval. Atmospheric Chemistry and Physics, Vol.6, pp.2727-2751.

Burrows, J. P., Hölze, E., Goede, A. P. H., Visser, H. \& Fricke, W. (1995). SCIAMACHY Scanning Imaging Absorption Spectrometer for Atmospheric Chartography. Acta Astronaut, Vol.35, No.7, pp.445-451.

Chahine, M. T., Thomas, S. P., Hartmut, H. A., Robert, A., Christopher, B., John, B., Luke, C., Murty, D., Eric, J. F., Mitch, G., Catherine, G., Stephanie, G., Scott, H., Fredrick, W. I., Ramesh, K., Eugenia, K., Bjorn, H. L., Sung-Yung, L., John, L. M., McMillan, W. W., Larry, M., Edward, O. T., Henry, R., Philip, R., William, S. L.,David, S., Strow, L. L., Joel, S., David, T., Walter, W. \& Lihang, Z. (2006). AIRS Improving Weather Forecasting and Providing New Data on Greenhouse Gases. American Meteorological Society, Vol.87, pp.911 -926.

Cheang, B. K. (1993). Interannual Variability of Monsoons In Malaysia and Its Relationship With ENSO. Proc. Indian Acad. Sci. (Earth Planet. Sci.), Vol 102, pp. 219-239.

Clerbaux, C., Hadji-Lazaro, J., Turquety, S., Mégie, G. \& Coheur, P. -F. (2003). Trace Gas Measurements From Infrared Satellite For Chemistry and Climate Applications. Atmospheric Chemistry and Physics, Vol.3, pp.1495-1508.

Clerbaux, C., Coheur, P. F., Hurtmans, D., Barret, B., Carleer, M., Colin, R., Semeniuk, K., McConnell, J. C., Boone, C. \& Bernath, P. (2005). Carbon Monoxide Distribution From The ACE-FTS Solar Occulation Measurements. Geophysical Research Letters, Vol.32, pp.1-4, DOI: 10.1029/2005GL022394.

Clerbaux, C., George, M., Turquety, S., Walker, K. A., Barret, B., Bernath, P., Boone, C., Borsdorff, T., Cammas, J. P., Catoire, V., Coffey, M., Coheur, P. -F., Deeter, M., De Mazière, M., Drummond, J., Duchatelet, P., Dupuy, E., de Zafra, R., Eddounia, F., Edwards, D. P., Emmons, L., Funke, B., Gille, J., Griffith, D. W. T., Hannigan, J., Hase, F., Höpfner, M., Jones, N., Kagawa, A., Kasai, Y., Kramer, I., Le Flochmoën, E., Livesey, N. J., López-Puertas, M., Luo, M., Mahieu, E., Murtagh, D., Nédélec, P., Pazmino, A., Pumphrey, H., Ricaud, P., Rinsland, C. P., Robert, C., Schneider, M., Senten, C., Stiller, G., Strandberg, A., Strong, K., Sussmann, R., Thouret, V., Urban, J. \& Wiacek, A. (2008). CO Measurements from The ACE-FTS Satellite Instrument: Data Analysis and Validation Using Ground-Based, Airborne and Spaceborne Observations. Atmospheric Chemistry and Physics, Vol.8, pp.2569-2594.

Daniel, J. S. \& Solomon, S. (1998). On The Climate Forcing of Carbon Monoxide. Journal of Geophysical Research, Vol.103, pp.13249-13260.

Dasimah, O. (2009). Urban Form and Sustainability of a Hot Humid City of Kuala Lumpur. European Journal of Social Sciences vol.8, pp.353-359.

De Groot, W. J., Field, R. D., Brady, M. A., Roswintiarti, O. \& Mohamad, M. (2007). Development of The Indonesian and Malaysian Fire Danger Rating Systems. Mitig Adapt Strat Glob Change, Vol.12, pp.165-180. 
Delaney, K., Ling, L., \& Erickson, T. (2001). In Ford Md, Clinical Toxicology, WB Saunders Company, ISBN 0-7216-5485-1.

Department of Environment (DOE), M. (2005). Malaysia Environmental Quality Report. Petaling Jaya.

Department Of Environment (DOE), M. (2009). Malaysia Environmental Quality Report. Petaling Jaya.

Dousset, B., \& Gourmelon, F. (2003). Satellite Multi-sensor Data Analysis of Urban Surface Temperatures and Landcover. ISPRS Journal of Photogrammetry and Remote Sensing, Vol 58, pp. 43-54.

Emmons, L. K., Pfister, G. G., Edwards, D. P., Gille, J. C., Sachse, G., Blake, D., Wofsy, S., Gerbig, C., Matross, D. \& Nedelec, P. (2007). Measurements of Pollution in the Troposphere (MOPITT) Validation Exercises During Summer 2004 Field Campaigns Over North America. Journal of Geophysical Research, Vol.112, D12S02, DOI: 10.1029/2006JD007833, 2007.

Emmons, L. K., Edwards, D. P., Deeter, M. N., Gille, J. C., Campos, T., Nédélec, P., Novelli, P. \& Sachse, G. (2009). Measurements of Pollution In The Troposhere (MOPITT) validation through 2006. Atmospheric Chemistry and Physics, Vol.9, pp.1795-1803.

Fishbein, E., Granger, S., Lee, S. Y., Manning, E., Weiler, M., Blaisdell, J., \& Susskind, J. (2007). AIRS/AMSU/HSB Version 5 Data Release User Guide. In Atmospheric Infrared Sounder, A., EOS, Ed., California Institute of Technology.

Fortems-Cheiney, A., Chevallier, F., Pison, I., Bousquet, P., Carouge, C., Clerbauz, C., Coheur, P. -F, George, M., Hurtmans, D. \& Szopa, S. (2009). On The Capability of IASI Measurements to Inform about CO Surface Emissions. Atmospheric Chemistry and Physics, Vol.9, pp.8735-8743.

Hoskins, A. J. (2001). Ozone Matters. Indoor and Built Environment, Vol.10, pp.1-2.

Jasim, M. R., MatJafri, M. Z., Lim, H. S. \& Abdullah, K. (2009). Indonesia Forest Fires Exacerbate Carbon Monoxide Pollution Over Peninsular Malaysia During July to September 2005. Proceedings of Sixth International Conference on Computer Graphics, Imaging and Visualization, DOI: 10.1109/CGIV.2009.96, Tianjin University, Tianjin, China, August, 2009.

Jasim, M. R., Lim, H. S., MatJafri, M. Z. \& Abdullah, K. (2010). Daily Carbon Monoxide (CO) Abundance from AIRS Over Peninsular Malaysia. Journal of Materials Science and Engineering, Vol.4, pp.93-99.

Jason, L. (2008). README Document for AIRS Level-2 Version 005 Standard Products. In Goddard Earth Sciences Data And Information Services Center (Ed., National Aeronautics and Space Administration (NASA).

Kopacz, M., Jacob, D. J., Fisher, J. A., Logan, J. A., Zhang, L., Megretskaia, I. A., Yantosca, R. M., Singh, K., Henze, D. K., Burrows, J. P., Buchwitz, M., Khlystova, I., McMillan, W. W., Gille, J. C., Edwards, D. P., Eldering, A., Thouret, V. \& Nedelec, P. (2010). Global Estimates of CO Sources with High Resolution by Adjoint Inversion of Multiple Satellite Datasets (MOPITT, AIRS, SCIAMACHY, TES). Atmospheric Chemistry and Physics, Vol.10, pp.855-876.

Lambrigtsen, B. H. (2003). Calibration of The AIRS Microwave Instruments. IEEE Transaction On Geoscience And Remote Sensing, Vol.41, No.2, pp.369-378.

Lavorel, S., Flannigan, M. D., Lambin, E. F. \& Scholes, M. C. (2007). Vulnerability of Land Systems to Fire: Interactions Among Humans, Climate, the Atmosphere, and Ecosystems. Mitig Adapt Strat Glob Change, Vol. 12, pp. 33-53.

Lawrence, M. G. (2004). Export of Air Pollution From Southern Asia and Its Large-Scale Effects. IN STOHL, A. (Ed.) The Handbook of Environmental Chemistry. Berlin, Springer. 
Liu, J., Drummond, J. R., Li, Q., Gille, J. C. \& Ziskin, D. C. (2005). Satellite Mapping of CO Emission from Forest Fires in Northwest America Using MOPITT Measurements. Remote Sensing of Environment, Vol.95, pp. 502-516.

Lopez, J. P., Luo, M., Christensen, L. E., Loewenstein, M., Jost, H., Webster, C. R. \& Osterman, G. (2008). TES Carbon Monoxide Validation during Two AVE Campaigns Using the Argus and ALIAS Instruments on NASA's WB-57F. Journal of Geophysical Research Atmospheres, Vol.113, D16S47, DOI: 10.1029/2007JD008811.

Luo, M., Rinsland, C. P., Fisher, B. M., Sachse, G., Diskin, G., Logan, J. A., Worden, H. M., Kulawik, S. S., Osterman, G., Eldering, A., Herman, R. \& Shephard, M. W. (2007). TES Carbon Monoxide Validation with DACOM Aircraft Measurement During INTEX-B 2006. Journal of Geophysical Research, Vol.112, D24S48, DOI: 10.1029/2007JD008803.

Mahmud, M. \& Kumar, T. S. V. V. (2008). Forecasting Severe Rainfall in the Equatorial Southeast Asia. GEOFIZIKA, Vol. 25, pp. 109-127.

Malaysian Meteorological Department (2009). General Climate of Malaysia. Selangor, Ministry of Science, Technology and Innovation (MOSTI).

McMillan, W. W., Barnet, C., Strow, L., Chahine, M. T., McCourt, M. L., Warner, J. X., Novelli, P. C., Korontzi, S., Maddy, E. S. \& Datta, S. (2005). Daily Global Maps of Carbon Monoxide From NASA's Atmospheric Infrared Sounder. Geophysical Research Letters, Vol.32, L11801, DOI: 10.1029/2004GL021821.

McMillan, W. W., Yurganov, L., Evans, K., \& Barnet, C. (2007). Global Climatology of Tropospheric CO from the Atmospheric InfraRed Sounder (AIRS). 20th Conference on Climate Varibility and Change, Vol. 5B.3, pp. 217 - 228.

McMillan, W. W., Warner, J. X., McCourt Comer, M., Maddy, E., Chu, A., Sparling, L., Eloranta, E., Hoff, R., Sachse, G., Barnet, C., Razenkov, I. \& Wolf, W. (2008). AIRS Views Transport from 12 to 22 July 2004 Alaskan/Canadian fires: Correlation of AIRS CO and MODIS AOD with Forward Trajectories and Comparison of AIRS CO Retrievals with DC-8 in Situ Measurements During INTEX-A/ICARTT. Journal of Geophysical Research, Vol.113, D20301, DOI: 10.1029/2007JD009711.

Nedelec, P., Cammas, J. -P, Thouret, V., Athier, G., Cousins, J. -M., Legrand, C., Abonnel, C., Lecoeur, F., Cayez, G. \& Marizy, C. (2003). An Improved Infrared Carbon Monoxide Analyzer for Routine Measurements aboard Commercial Airbus Aircraft: Technical Validation and First Scientific Results of The MOZAIC III Programme. Atmospheric Chemistry and Physics, Vol.3, pp.1551-1564.

Pagano, T. S., Aumann, H. H., Hagan, D. E. \& Overoye, K. (2003). Prelaunch and In-Flight Radiometric Calibration of The Atmospheric Infrared Sounder (AIRS). IEEE Transactions on Geoscience and Remote Sensing, Vol.41, pp.265 - 273.

Pagano, T. S., Chahine, M. T., Aumann, H. H., Tian, B., Lee, S. Y., Olsen, E., Lambrigtsen, B., Fetzer, E., Irion, F. W., McMillan, W., Strow, L., Fu, X., Barnet, C., Goldberg, M., Susskind, J. \& Blaisdell, J. (2006). Remote Sensing of Atmospheric Climate Parameters from the Atmospheric Infrared Sounder. IEEE International Geosience and Remote Sensing Symposium (IGARSS), pp.2386-2389, ISBN: 0780395107.

Pochanart, P., Akimoto, H., Kajii, Y. \& Sukasem, P. (2003). Carbon Monoxide, Regional-Scale Transport, and Biomass Burning in Tropical Continental Southeast Asia: Observations in Rural Thailand. Journal of Geophysical Research, Vol.108, pp. 4552, 15.

Pochanart, P., Wild, O. \& Akimoto, H. (2004). Air Pollution Import To and Export From East Asia. IN STOHL, A. (Ed.) The Handbook of Environmental Chemistry. Berlin, Springer. 
Rasch, P. J., Collins, W. D. \& Eaton, B. E. (2001). Understanding the Indian Ocean Experiment (INDOEX) Aerosol Distributions with an Aerosol Assimilation. Journal of Geophysical Research, Vol.106, pp.7337-7355.

Shaharuddin, A. \& Mohamed, E. Y. (2005). Urban climate research in Malaysia. IAUC Newsletter, 5-10.

Streets, D., Tsai, N., Akimoto, H. \& Oka, K. (2001). Trends in Emissions of Acidifying Species in Asia, 1987-1997. Water, Air, and Soil Pollution, Vol.130, pp. 187-192.

Strow, L. L, Hannon, S. E., Souza-Machado, S. D., Motteler, H. E. \& Tobin, D. (2003). An Overview of the AIRS Radiative Transfer Model. IEEE Transaction on Geoscience and Remote Sensing, Vol.41, No.2, pp.303-313.

Suhaila, J. \& Jemain, A. A. (2007). Fitting Daily Rainfall Amount in Malaysia using the Normal Transform Distribution. Journal of Applied Sciences, Vol.7, pp.1880 - 1886.

Suhaila, J. \& Jemain, A. A. (2009). Investigating the Impacts of Adjoining Wet Days on the Distribution of Daily Rainfall Amounts in Peninsular Malaysia. Journal of Hydrology, Vol.368, pp.17-25.

Tangang, F. T., Juneng, L. \& Ahmad, S. (2007). Trend and Interannual Variability of Temperature in Malaysia: 1961-2002. Theoretical and Applied Climatology, Vol.89, pp.127-141.

Tiwari, Y. K., Gloor, M., Engelen, R., Rodenbeck, C. \& Heimann, M. (2005). Comparing Model Predicted Atmospheric $\mathrm{CO}_{2}$ with Satellite Retrievals and In-situ Observations - Implications for the Use of Upcoming Satellite Data in Atmospheric Inversions. Geophysical Research Abstracts, Vol. 7, 09823.

Turquety, S., Hurtmans, D., Hadji-Lazaro, J., Coheur, P. -F, Clerbauz, C., Josset, D. \& Tsamalis, C. (2009). Tracking the Emission and Transport of Pollution from Wildfires Using the IASI CO Retrievals: Analysis of the Summer 2007 Greek fires. Atmospheric Chemistry and Physics, Vol.9, pp.4897-4913.

Varikoden, H., Samah, A. A. \& Babu, C. A. (2010). Spatial and Temporal Characteristics of Rain Intensity in The Peninsular Malaysia Using TRMM Rain Rate. Journal of Hydrology, Vol.387, pp.312-319.

Warner, J., Comer, M. M., Barnet, C. D., McMillan, W. W., Wolf, W., Maddy, E. \& Sachse, G. (2007). A Comparison of Satellite Tropospheric Carbon Monoxide Measurements from AIRS and MOPITT during INTEX-A. Journal of Geophysical Research, Vol.112, D12S17.

Wong, C. L., Venneker, R., Uhlenbrook, S., Jamil, A. B. M. \& Zhou, Y. (2009). Variability of Rainfall in Peninsular Malaysia. Journal Hydrology and Earth System Sciences Discussions, Vol. 6, pp.5471-5503.

Ye, H., Fetzer, E. J., Bromwich, D. H., Fishbein, E. F., Olsen, E. T., Granger, S. L., Lee, S. Y., Chen, L. \& Lambrigtsen, B. H. (2007). Atmospheric Total Precipitable Water from AIRS and ECMWF during Antarctic Summer. Geophysical Research Letters, Vol.34, L19701.

Yurganov, L., McMillan, W., Wilson, C., Fischer, M. \& Biraud, S. (2010). Carbon Monoxide Mixing Ratios over Oklahoma Between 2002 and 2009 Retrieved from Atmospheric Emitted Radiance Interferometer Spectra. Atmospheric Measurement Techniques, Vol. 3, pp. 1263-1301. 


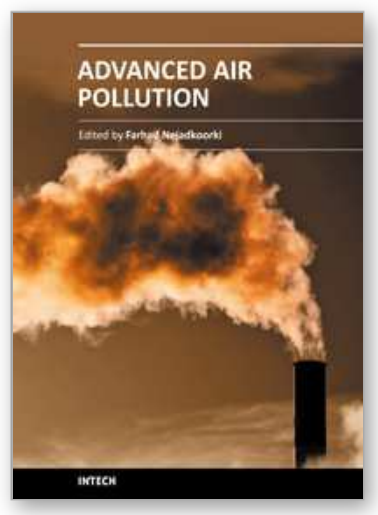

\author{
Advanced Air Pollution \\ Edited by Dr. Farhad Nejadkoorki
}

ISBN 978-953-307-511-2

Hard cover, 584 pages

Publisher InTech

Published online 17, August, 2011

Published in print edition August, 2011

Leading air quality professionals describe different aspects of air pollution. The book presents information on four broad areas of interest in the air pollution field; the air pollution monitoring; air quality modeling; the GIS techniques to manage air quality; the new approaches to manage air quality. This book fulfills the need on the latest concepts of air pollution science and provides comprehensive information on all relevant components relating to air pollution issues in urban areas and industries. The book is suitable for a variety of scientists who wish to follow application of the theory in practice in air pollution. Known for its broad case studies, the book emphasizes an insightful of the connection between sources and control of air pollution, rather than being a simple manual on the subject.

\title{
How to reference
}

In order to correctly reference this scholarly work, feel free to copy and paste the following:

Jasim M. Rajab, K. C. Tan, H. S. Lim and M. Z. MatJafri (2011). Investigation on the Carbon Monoxide Pollution over Peninsular Malaysia Caused by Indonesia Forest Fires from AIRS Daily Measurement, Advanced Air Pollution, Dr. Farhad Nejadkoorki (Ed.), ISBN: 978-953-307-511-2, InTech, Available from: http://www.intechopen.com/books/advanced-air-pollution/investigation-on-the-carbon-monoxide-pollution-overpeninsular-malaysia-caused-by-indonesia-forest-f

\section{INTECH}

open science | open minds

\author{
InTech Europe \\ University Campus STeP Ri \\ Slavka Krautzeka 83/A \\ 51000 Rijeka, Croatia \\ Phone: +385 (51) 770447 \\ Fax: +385 (51) 686166 \\ www.intechopen.com
}

\author{
InTech China \\ Unit 405, Office Block, Hotel Equatorial Shanghai \\ No.65, Yan An Road (West), Shanghai, 200040, China \\ 中国上海市延安西路65号上海国际贵都大饭店办公楼 405 单元 \\ Phone: +86-21-62489820 \\ Fax: +86-21-62489821
}


(C) 2011 The Author(s). Licensee IntechOpen. This chapter is distributed under the terms of the Creative Commons Attribution-NonCommercialShareAlike-3.0 License, which permits use, distribution and reproduction for non-commercial purposes, provided the original is properly cited and derivative works building on this content are distributed under the same license. 